University of Nebraska - Lincoln

DigitalCommons@University of Nebraska - Lincoln

Biological Systems Engineering: Papers and

Publications

Biological Systems Engineering

1996

\title{
Heat Curing of Soy Protein Films
}

\author{
A. Gennadios \\ University of Nebraska-Lincoln, aris.gennadios@catalent.com \\ V. M. Ghorpade \\ University of Nebraska-Lincoln \\ Curtis L. Weller \\ University of Nebraska-Lincoln, cweller1@unl.edu
}

M. A. Hanna

University of Nebraska-Lincoln, mhanna1@unl.edu

Follow this and additional works at: https://digitalcommons.unl.edu/biosysengfacpub

Part of the Biological Engineering Commons

Gennadios, A.; Ghorpade, V. M.; Weller, Curtis L.; and Hanna, M. A., "Heat Curing of Soy Protein Films" (1996). Biological Systems Engineering: Papers and Publications. 94.

https://digitalcommons.unl.edu/biosysengfacpub/94

This Article is brought to you for free and open access by the Biological Systems Engineering at DigitalCommons@University of Nebraska - Lincoln. It has been accepted for inclusion in Biological Systems Engineering: Papers and Publications by an authorized administrator of DigitalCommons@University of Nebraska Lincoln. 


\title{
Heat Curing of Soy Protein Films
}

\author{
A. Gennadios, V. M. Ghorpade, C. L. Weller, M. A. Hanna
}

\begin{abstract}
Modification of soy protein film properties by heat-curing was studied. Glycerin-plasticized films were cast from alkaline aqueous solutions of soy protein isolate. Films were heated at 80 or $95^{\circ} \mathrm{C}$ for $2,6,14$, or 24 h. Tensile strength (TS), elongation at break (E), moisture content $(M C)$, water solubility (WS), water vapor permeability (WVP), and color of heated and control films were measured. Heated films had increased TS and $+b$ (yellowness) Hunter color values and reduced E, MC, WS, and WVP values. These effects were enhanced as heating time and temperature increased. Keywords. Protein films, Soy protein, Edible films, Tensile strength, Water vapor permeability.
\end{abstract}

$\mathrm{D}$ evelopment of biopolymer films and coatings from protein, polysaccharide, and lipid materials has received increased interest in recent years. In the midst of rising concerns over solid packaging waste, the renewable nature of biopolymer film ingredients renders such films particularly appealing for innovative uses in the field of packaging. Furthermore, as many of these film-forming biopolymers are edible, applications of edible packaging in the area of food packaging and preservation can be realized if edibility is maintained throughout the film production process. From an agricultural industry perspective, wide commercialization of biopolymer films would lead to further utilization of agricultural commodities employed as sources of film-forming materials.

Films and coatings based on proteins, such as wheat gluten, corn zein, soy protein, peanut protein, milk proteins, collagen, and gelatin, have been reviewed by Gennadios et al. (1994a). Several recent studies have concentrated on the development and property evaluation of soy protein isolate films in particular (Brandenburg et al., 1993; Gennadios et al., 1993a, 1994b; Shih, 1994; Stuchell and Krochta, 1994; Ghorpade et al., 1995). A variety of methods have been employed to modify soy protein film properties including treatment with alkali (Brandenburg et al., 1993); alkylation with sodium alginate (Shih, 1994); treatment with propyleneglycol alginate (Shih, 1994); enzymatic treatment with horseradish peroxidase (Stuchell and Krochta, 1994); acylation with

\footnotetext{
Article was submitted for publication in July 1995; reviewed and approved for publication by the Food and Process Engineering Inst. of ASAE in October 1995. Presented as ASAE Paper No. 94-6552.

Journal Series No. 11206, Agricultural Research Division, Institute of Agriculture and Natural Resources, University of Nebraska, Lincoln.

The authors are Aristippos Gennadios, ASAE Member, Post-doctoral Research Associate, Viswas Ghorpade, ASAE Member, Assistant Professor, Curtis L. Weller, ASAE Member Engineer, Associate Professor, and Milford A. Hanna, ASAE Member Engineer, Professor, Dept. of Biological Systems Engineering, University of Nebraska, Lincoln. Corresponding author: Milford A. Hanna, Dept. of Biological Systems Engineering, University of Nebraska, 211 L.W. Chase Hall, East Campus, Lincoln, NE 68583-0726; telephone: 402-472-1634; e-mail: <bsen024@unlvm.unl.edu>.
}

acetic and succinic anhydrides (Ghorpade et al., 1995); and treatment with formaldehyde (Ghorpade et al., 1995).

A few studies have shown that heat-treating prepared protein films and coatings or film-forming protein solutions had a noticeable effect on film properties. Heating of corn zein-epoxy resin films at elevated temperatures (i.e., $145^{\circ} \mathrm{C}$ for $30 \mathrm{~min}$ or $200^{\circ} \mathrm{C}$ for $5 \mathrm{~min}$ ) increased film toughness and water resistance (Howland, 1961; Howland and Reiners, 1962). Increased water resistance also was reported by Julius (1967) for heat-cured zein, gelatin, and fibrin protein films. Kolster et al. (1992) heated wheat gluten films at $80^{\circ} \mathrm{C}$ and found that film stress increased, whereas film strain decreased, as the heating time increased. Roy et al. (1995) heated wheat gluten film-forming solutions at $55,65,75,85$, or $95^{\circ} \mathrm{C}$ for 10 min prior to casting. Reportedly, film tensile strength (TS) and percent elongation (E) at break increased, and solubility of film in water decreased with increasing temperature. In another study, Stuchell and Krochta (1994) cast films from unheated and heated $\left(85^{\circ} \mathrm{C}\right)$ soy protein isolate film-forming solutions. Films from heated solutions had lower water vapor permeability and were more flexible than unheated control films.

The objective of this study was to determine the effect of heating on selected physical properties of soy protein isolate (SPI) films cast from alkaline aqueous solutions.

\section{MATERIALS AND METHODS Film Preparation}

Film-forming solutions were prepared by mixing $100 \mathrm{~mL}$ of distilled water, $5 \mathrm{~g}$ of SPI (ARPRO 1100, 93.5\% d.b. protein content, obtained gratis from Archer Daniels Midland Company, Decatur, Ill.), and $3 \mathrm{~g}$ of glycerin (Fisher Scientific, Pittsburgh, Pa.). Glycerin was added as plasticizer to overcome film brittleness and to obtain free-standing films. Sodium hydroxide $(1 \mathrm{~N})$ was used to adjust the $\mathrm{pH}$ to $11.0 \pm 0.1$. Alkaline conditions have been shown to favor soy protein film formation, presumably, by aiding protein dispersion in the filmforming solutions (Gennadios et al., 1993a). However, high $\mathrm{pH}$ values may compromise the films' edibility. The solutions were held for $30 \mathrm{~min}$ in a $70^{\circ} \mathrm{C}$ constant 
temperature waterbath, strained through cheese cloth (Grade 40, Fisher Scientific, Pittsburgh, Pa.) to remove air bubbles formed during stirring, and cast on level Teflon ${ }^{\circledR}$ coated glass plates. Films were peeled from the plates after drying at ambient temperature for about $30 \mathrm{~h}$. Dried films had a thickness of $96.5 \pm 4.6 \mu \mathrm{m}$ (mean of 30 thickness measurements).

\section{Heating}

Dried films were mounted on glass plates by applying masking tape around the film edges and heated at 80 or $95^{\circ} \mathrm{C}$ in an air-circulating oven for $2,6,14$, or $24 \mathrm{~h}$. Masking tape held films flat and prevented curling and rippling during heating. Property evaluation on curled film samples was meaningless since no reliable thickness measurements could be obtained. However, it should be noted that the practice of applying masking tape may have caused some stress development within the films. Following the heat treatment, films were appropriately conditioned for property evaluation. More severe heat treatments were not applied to the films to avoid evaporative losses of glycerin. The boiling point of pure glycerin at atmospheric pressure is $290^{\circ} \mathrm{C}$, but drops substantially in the presence of water (Gregory, 1991).

\section{Moisture Content}

Films were stored for three days in an environmental chamber maintained at $25^{\circ} \mathrm{C}$ and $50 \% \mathrm{RH}$ (relative humidity). These conditions were similar to those of conditioning film specimens prior to tensile testing. Subsequently, samples of 300 to $400 \mathrm{mg}$ were weighed into aluminum dishes and dried for $24 \mathrm{~h}$ in an air-circulating oven at $105^{\circ} \mathrm{C}$. Moisture content (MC) was determined in triplicate for each type of film as percentage of initial film weight lost during drying and reported on a wet basis.

\section{Tensile Strength and Elongation}

Tensile strength (TS) and elongation at break (E) were both measured with a model 5566 Instron Universal Testing Machine (Instron Corp., Canton, Mass.) following the guidelines of ASTM Standard Method D 882-88 (American Society for Testing and Materials, 1989). Film specimens $(2.54 \mathrm{~cm}$ wide and $15 \mathrm{~cm}$ long) were cut. Five thickness measurements were taken along each specimen with a micrometer (B.C. Ames Co., Waltham, Mass.) and the mean of the five measurements was used in the TS calculation. Initial grip separation and cross-head speed were set at 10 and $5 \mathrm{~cm} / \mathrm{min}$, respectively. In an apparent deviation from ASTM Standard Method D 882-88, tensile testing of film samples was conducted, as quickly as possible, in ambient conditions rather than in the recommended Standard Laboratory Atmosphere of $23 \pm$ $2^{\circ} \mathrm{C}$ and $50 \pm 5 \% \mathrm{RH}$. Tensile strength was calculated by dividing peak load by initial specimen cross-sectional area. Elongation was expressed as the percentage of change of the original length of the specimen between the grips (10 $\mathrm{cm})$. Prior to tensile testing, film specimens were conditioned for three days in an environmental chamber set at $50 \% \mathrm{RH}$ and $25^{\circ} \mathrm{C}$. Both TS and E values for each type of film were determined in triplicate with individually prepared, cast, and heated films as the replicated experimental units. Each TS and E replicate was the mean of six tested sampling units (specimens) taken from the same film.

\section{WATER Solubility}

Films were stored for one week in a desiccator cabinet equilibrated to $0 \% \mathrm{RH}$ with calcium sulfate (Drierite, Fisher Scientific, Pittsburgh, Pa.). Samples weighing 10 to $20 \mathrm{mg}$ were immersed in $5 \mathrm{~mL}$ of distilled water in test tubes. Tube openings were covered with Saran ${ }^{\circledR}$ wrap and the samples were incubated at room temperature for $24 \mathrm{~h}$ with periodical gentle agitation. Protein concentration $(\mathrm{mg} / \mathrm{mL})$ was calculated using a bicinchoninic acid (BCA) protein assay (Smith et al., 1985). Water solubility (WS) results were expressed as the percentage of total protein detected in the solution (based on initial dry film weight after accounting for both the protein:glycerin ratio in the film and the protein content of the used commercial SPI product). Water solubility values were obtained in triplicate for each type of film.

\section{Water Vapor Permeability}

Film specimens $7 \times 7 \mathrm{~cm}$ were cut. Five thickness measurements were taken on each specimen, one at the center and four around the perimeter, and their mean was used as the specimen thickness in water vapor permeability (WVP) calculations. Prior to testing, all film specimens were conditioned for two days in an environmental chamber set at $25^{\circ} \mathrm{C}$ and $50 \% \mathrm{RH}$. Three film specimens, each from an individually cast and heated film, were tested for each type of film. The WVP $\left(\mathrm{g} \cdot \mathrm{m} / \mathrm{m}^{2} \cdot \mathrm{s} \cdot \mathrm{Pa}\right)$ was calculated as:

$$
\mathrm{WVP}=(\mathrm{WVTR} \cdot \mathrm{L}) / \Delta \mathrm{p}
$$

where

WVTR $=$ measured water vapor transmission rate $\left(\mathrm{g} / \mathrm{m}^{2} \cdot \mathrm{s}\right)$ through a film specimen

$\mathrm{L} \quad=$ mean film specimen thickness $(\mathrm{m})$

$\Delta \mathrm{p} \quad=$ partial water vapor pressure difference $(\mathrm{Pa})$ between the two sides of the film specimen

Water vapor transmission rate was determined gravimetrically using a modification of ASTM Standard Method E 96-80 (American Society for Testing and Materials, 1989). Film specimens were mounted on poly(methylmethacrylate) cups filled with distilled water up to $1 \mathrm{~cm}$ from the film underside. The design of the cups was described by Gennadios et al. (1994c). The cups were placed in an environmental chamber set at $25^{\circ} \mathrm{C}$ and $50 \%$ RH. A fan was operated within the chamber creating an air velocity of $198 \mathrm{~m} / \mathrm{min}$ over the surface of the cups to remove the permeating water vapor. The weights of the cups were recorded six times at 1-h intervals. Steady state was reached within $2 \mathrm{~h}$. Linear regression-derived slopes of the steady state (linear) portion of weight loss versus time curves were used to estimate WVTR. Because of the low water vapor resistance of protein-based films, the actual RH values at the film undersides during testing were lower than the theoretical value of $100 \%$. These actual $\mathrm{RH}$ values at the film undersides inside the cups and the film WVP values were calculated after accounting for the resistance of the stagnant air layer between the film undersides and the water surface in the cups (McHugh et al., 1993; 
Gennadios et al., 1994c). The mean of the initial and final stagnant air gap height was used in the calculations.

\section{Color Values}

Color values of soy protein films were measured with a CR-300 Minolta Chroma Meter (Minolta Camera Co., Ltd., Osaka, Japan). This instrument is a tristimulus color analyzer with an 8-mm-diameter measuring area. Film specimens were placed on the surface of a white standard plate (Calibration Plate CR-A43) and Hunter L, a, and b color values were measured. The three color coordinates range from $\mathrm{L}=0$ (black) to $\mathrm{L}=100$ (white), $-\mathrm{a}$ (greenness) to $+\mathrm{a}$ (redness), and $-\mathrm{b}$ (blueness) to $+\mathrm{b}$ (yellowness) (Francis and Clydesdale, 1975). Total color difference $(\Delta \mathrm{E})$ was calculated from:

$$
\begin{gathered}
\Delta E=\left[\left(L_{\text {film }}-L_{\text {standard }}\right)^{2}+\left(a_{\text {film }}-a_{\text {standard }}\right)^{2}\right. \\
\left.+\left(b_{\text {film }}-b_{\text {standard }}\right)^{2}\right]^{0.5}
\end{gathered}
$$

Standard values refer to the white calibration plate $(\mathrm{L}=96.86, \mathrm{a}=-0.02, \mathrm{~b}=1.99)$. Measurements were taken in triplicate for each type of film.

\section{Statistical Analysis}

Statistics on a completely randomized design were determined using the general linear models procedure in SAS (SAS Institute, 1988). Duncan's multiple range test $(P<0.05)$ was used to detect differences among WVP and Hunter $\mathrm{L}, \mathrm{a}, \mathrm{b}$, and $\Delta \mathrm{E}$ mean values at different combinations of heating time and temperature. Linear regression equations were fitted to $\mathrm{E}$ and WS data of heated films with the REG procedure in SAS (SAS Institute, 1988). Power regression equations were fitted to MC and TS data of heated films with the NLIN procedure in SAS (SAS Institute, 1988).

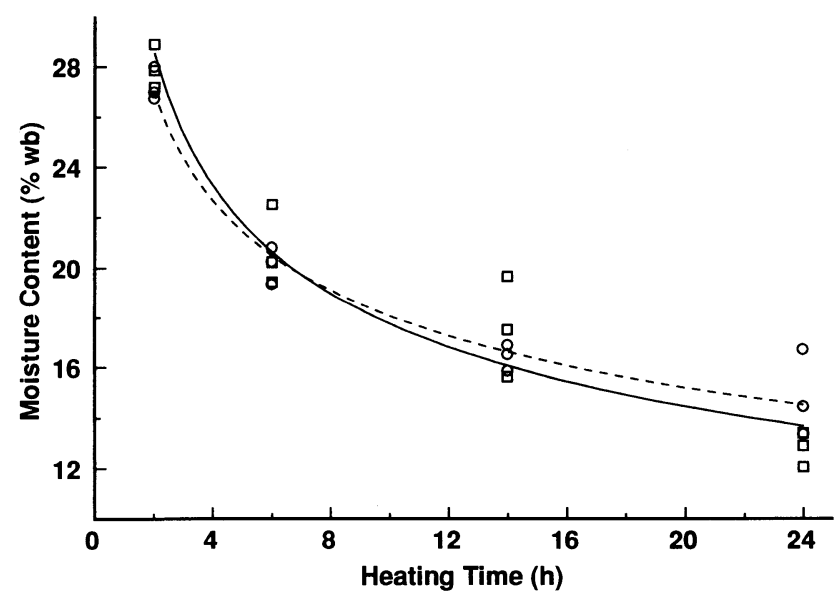

Figure 1-Moisture content values of soy protein isolate films heated at $80^{\circ} \mathrm{C}$ ( $O$ with dashed line) and $95^{\circ} \mathrm{C}$ ( $\square$ with solid line) after storage at $50 \% \mathrm{RH}$ and $25^{\circ} \mathrm{C}$ for three days. Power regression lines $\left(r=0.983\right.$ and $r=0.966$ for 80 and $95^{\circ} \mathrm{C}$, respectively) were fitted to the data.

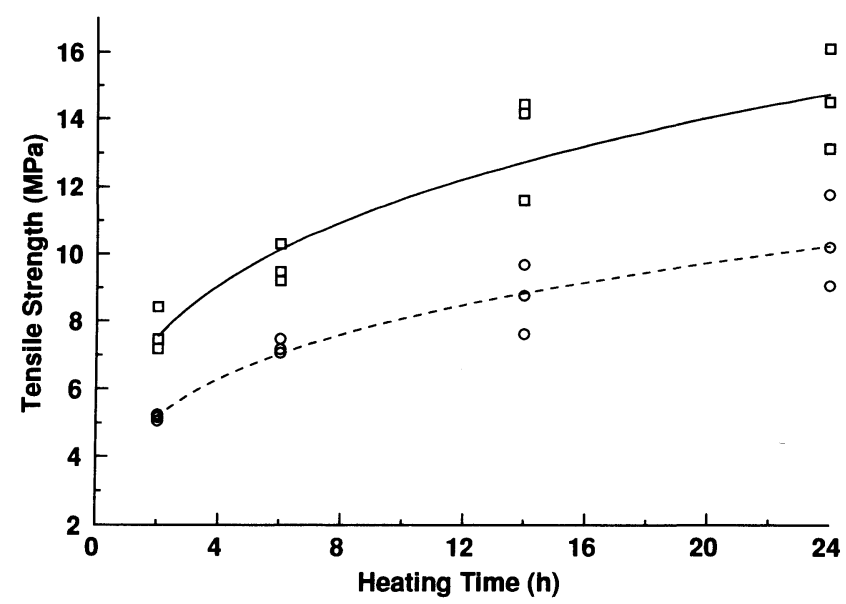

Figure 2-Tensile strength of soy protein isolate films heated at $80^{\circ} \mathrm{C}$ ( $O$ with dashed line) and $95^{\circ} \mathrm{C}$ ( $\square$ with solid line). Power regression lines $\left(r=0.936\right.$ and $r=0.936$ for 80 and $95^{\circ} \mathrm{C}$, respectively) were fitted to the data.

\section{RESULTS AND DiSCUSSION MOISTURE CONTENT}

The MC (wet basis) of unheated SPI films after storage at $50 \% \mathrm{RH}$ and $25^{\circ} \mathrm{C}$ for three days was $28.5 \pm 0.8 \%$. As shown in figure 1 , film moisture content decreased as a result of heating. Across all levels of heating time, there were no significant $(\mathrm{P}>0.05)$ differences in $\mathrm{MC}$ between films heated at $80^{\circ} \mathrm{C}$ and films heated at $95^{\circ} \mathrm{C}$.

\section{Tensile Strength and Elongation}

Unheated SPI films had a TS (maximum tensile stress a film can sustain) value of $3.25 \pm 0.06 \mathrm{MPa}$. Film TS increased with heating time at both 80 and $95^{\circ} \mathrm{C}$ (fig. 2). Heat treatment at $95^{\circ} \mathrm{C}$ yielded films with significantly $(\mathrm{P}<0.05)$ higher TS than heat treatment at $80^{\circ} \mathrm{C}$ across all levels of heating time. On average, films heated at $95^{\circ} \mathrm{C}$ had TS values $3.48 \pm 0.45 \mathrm{MPa}$ greater than films heated for the same time at $80^{\circ} \mathrm{C}$.

In contrast to TS, heating decreased film $\mathrm{E}$ (a measure of a film's ability to stretch) from an initial value of $111.9 \pm$ $12.4 \%$ for unheated films (fig. 3). This heat-induced

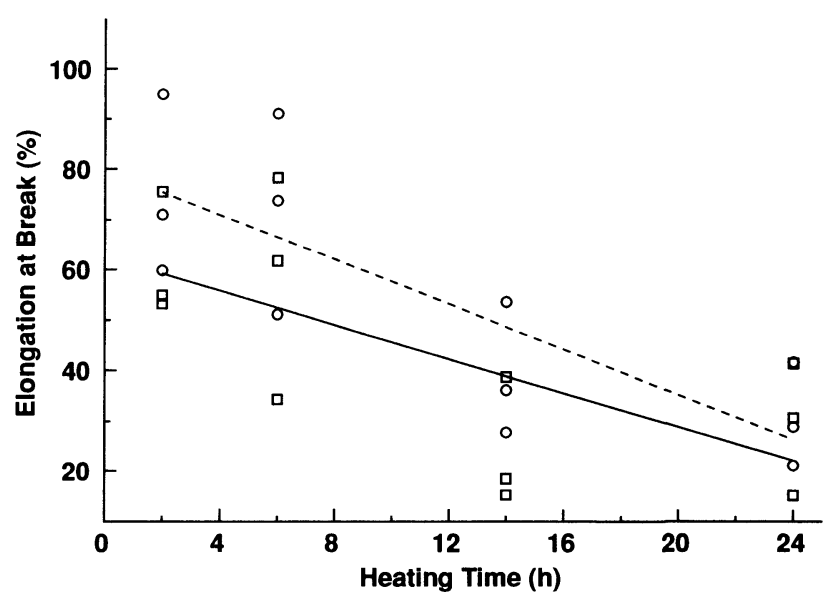

Figure 3-Elongation at break of soy protein isolate films heated at $80^{\circ} \mathrm{C}$ ( $O$ with dashed line) and $95^{\circ} \mathrm{C}$ ( $\square$ with solid line). Linear regression lines $\left(R^{2}=0.64\right.$ and $R^{2}=0.45$ for 80 and $95^{\circ} \mathrm{C}$, respectively) were fitted to the data. 
decrease in $\mathrm{E}$ was more pronounced as the duration of the heat treatment increased at both 80 and $95^{\circ} \mathrm{C}$ (fig. 3). Across all levels of heating time, $\mathrm{E}$ values of films heated at $80^{\circ} \mathrm{C}$ were not significantly $(\mathrm{P}>0.05)$ different than $\mathrm{E}$ values of films heated at $95^{\circ} \mathrm{C}$.

Similar to the results of the present study, increases in film TS and decreases in film $E$ also were observed for wheat gluten protein films heat-treated at $80^{\circ} \mathrm{C}$ (Kolster et al., 1992). The effect of heating on film TS and $E$ values can be partially attributed to the development of heat-induced cross-linking within the film structure. According to Cheftel et al. (1985), thermal treatments of proteins at alkaline $\mathrm{pH}$ (such as the $\mathrm{pH}$ of SPI films in the present study) promote formation of intra- and intermolecular cross-links. Such cross-links result from condensation of lysine, cysteine, or ornithine amino acid residues with a residue of dehydroalanine, the latter being formed by a $\beta$-elimination reaction starting with cysteine or phosphoserine residues (Cheftel et al., 1985). Presumably, such cross-links contributed to the increased toughness (higher TS) and reduced flexibility (lower E) of heated SPI films.

Besides heat-induced cross-linking, differences in MC also were considered as contributing factors to the observed increases in TS and decreases in E of heated SPI films. It has been shown that water functions as a plasticizer of wheat gluten and corn zein protein films reducing film TS and increasing film $\mathrm{E}$ (Gennadios et al., 1993b; Gontard et al., 1993). As mentioned earlier, the MC of SPI films (stored at conditions similar to those of conditioning films prior to tensile testing) decreased with heating time. As a result, the plasticizing effect of water was lessened as the duration of film heat treatment increased.

\section{WATER SolubiLITY}

Heat-treated SPI films had substantially lower WS values (fig. 4) than the WS of $17.2 \pm 1.2 \%$ recorded for unheated films. Across all heating times, films heated at $95^{\circ} \mathrm{C}$ had significantly $(\mathrm{P}<0.05$ ) lower (by $5.4 \pm 0.3 \%$ ) WS values than films heated at $80^{\circ} \mathrm{C}$.

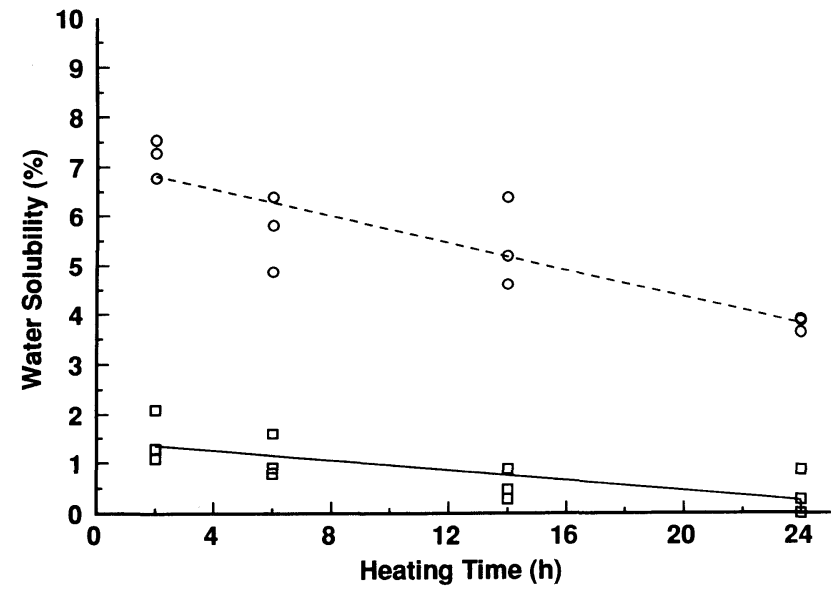

Figure 4-Water solubility values of soy protein isolate films heated at $80^{\circ} \mathrm{C}$ ( $O$ with dashed line) and $95^{\circ} \mathrm{C}$ ( $\square$ with solid line). Linear regression lines $\left(R^{2}=0.77\right.$ and $R^{2}=0.55$ for 80 and $95^{\circ} \mathrm{C}$, respectively) were fitted to the data.
The drastic reduction of WS for most proteins subjected to heat treatment is well documented in the literature (Cheftel et al., 1985). Reductions in WSs following heat treatments have been reported for corn zein, gelatin, and fibrin protein films (Howland, 1961; Howland and Reiners, 1962; Julius, 1967).

\section{Water Vapor Permeability}

The WVP values, along with actual RH conditions at the undersides of films during testing, of control and heated SPI films are presented in table 1. A reduction in film WVP was evidenced as heating times increased for both 80 and $95^{\circ} \mathrm{C}$. It also was noticed that the actual $\mathrm{RH}$ at the inner film surface, and, therefore, the $\mathrm{RH}$ gradient applied across the films during testing, increased with the severity of the heat treatment. Therefore, the observed differences in WVP values of SPI films would have been even greater under equal RH gradient conditions across the films. Films heated at $95^{\circ} \mathrm{C}$ had significantly $(\mathrm{P}<0.05)$ lower WVP than films heated at $80^{\circ} \mathrm{C}$ for 2 and $6 \mathrm{~h}$ of heating time. For heating times of 14 and $24 \mathrm{~h}$, films heated at $95^{\circ} \mathrm{C}$ had lower, but not significantly $(P>0.05)$, WVP mean values than films heated at $80^{\circ} \mathrm{C}$. The decrease in WVP of heated films can be attributed to: 1) formation of covalent links within the films during heating; and 2) lower WS of heated films, an indication of a decrease in protein hydrophilicity.

\section{COLOR}

Color characteristics of films can be important factors for consumer acceptance of such films in edible or nonedible packaging applications. The Hunter $\mathrm{L}, \mathrm{a}$, and $\mathrm{b}$ color values and the total color difference $(\Delta \mathrm{E})$ values of control and heated SPI films are presented in table 2 . The main difference between heated and unheated control films was the increased positive $b$ values (yellowness) of heated films. The length of heating did not seem to be important to the film color; however, the temperature of heating was important. Films heated at $95^{\circ} \mathrm{C}$ had greater $(\mathrm{P}<0.05)$ positive $b$ (yellowness) and negative a (redness) values, and, consequently, higher $\Delta \mathrm{E}$ values than films heated at $80^{\circ} \mathrm{C}$. It is noted that color measurements of films may be affected by film moisture content and thickness. For example, films thicker than the ones prepared in this study (96.5 $\pm 4.6 \mu \mathrm{m})$ would appear more yellowish (higher positive $b$ values).

Table 1. Effect of heating at 80 and $95^{\circ} \mathrm{C}$ on WVP of soy protein isolate films (96.5 $\pm 4.6 \mu \mathrm{m}$ in thickness) calculated using the ASTM E 96-80 Method at $25^{\circ} \mathrm{C}$

\begin{tabular}{|c|c|c|c|c|}
\hline \multirow[b]{2}{*}{$\begin{array}{l}\text { Heating Tim } \\
\text { (h) }\end{array}$} & \multicolumn{2}{|c|}{$80^{\circ} \mathrm{C}$} & \multicolumn{2}{|c|}{$95^{\circ} \mathrm{C}$} \\
\hline & $\begin{array}{c}\text { WVP* } \\
\times 10^{-9}\left(\mathrm{~g} \cdot \mathrm{m} / \mathrm{m}^{2} \cdot \mathrm{s} \cdot \mathrm{Pa}\right)\end{array}$ & $\begin{array}{c}\text { RH Inside Cup } \dagger \\
(\%)\end{array}$ & $\begin{array}{c}\text { WVP* } \\
\times 10^{-9}\left(\mathrm{~g} \cdot \mathrm{m} / \mathrm{m}^{2} \cdot \mathrm{s} \cdot \mathrm{Pa}\right)\end{array}$ & $\begin{array}{c}\text { RH Inside Cup }{ }^{\dagger} \\
(\%)\end{array}$ \\
\hline 0 & $3.61 \pm 0.27 \mathrm{a}$ & $67.22 \pm 0.96$ & $3.61 \pm 0.27 a$ & $67.22 \pm 0.96$ \\
\hline 2 & $3.12 \pm 0.28 b$ & $69.14 \pm 0.85$ & $2.49 \pm 0.23 c$ & $70.94 \pm 1.10$ \\
\hline 6 & $2.64 \pm 0.28 c$ & $69.91 \pm 0.42$ & $1.91 \pm 0.14 d$ & $72.68 \pm 0.17$ \\
\hline 14 & $2.00 \pm 0.25 \mathrm{~d}$ & $73.62 \pm 0.11$ & $1.71 \pm 0.05 \mathrm{~d}$ & $74.46 \pm 0.19$ \\
\hline 24 & $1.73 \pm 0.17 \mathrm{~d}$ & $74.45 \pm 0.10$ & $1.64 \pm 0.05 d$ & $75.25 \pm 0.06$ \\
\hline \multicolumn{5}{|c|}{$\begin{array}{l}\text { WVP values are means of three replicates plus/minus a standard deviation. Any two } \\
\text { WVP means followed by the same small-case letter are not significantly }(P>0.05) \\
\text { different according to Duncan's multiple range test. }\end{array}$} \\
\hline \multicolumn{5}{|c|}{$\begin{array}{l}\text { Actual RH values (means of three replicates plus/minus a standard deviation) at the } \\
\text { underside of films calculated as described by Gennadios et al. (1994c) to account for } \\
\text { resistance of stagnant air layer between film and water surface in testing cups. RH } \\
\text { outside cups was } 50 \% \text {. }\end{array}$} \\
\hline
\end{tabular}


Table 2. Hunter color values $(\mathrm{L}, \mathrm{a}$, and $\mathrm{b})$ and total color difference $(\Delta E)$ for soy protein films heated at 80 and $95^{\circ} \mathrm{C}$ for various times* +

\begin{tabular}{ccccc}
\multicolumn{5}{c}{ for soy protein films heated at 80 and $95^{\circ} \mathbf{C}$ for various times* } \\
$\begin{array}{l}\text { Heating } \\
\text { Time }(\mathrm{h})\end{array}$ & $\mathrm{L}$ & $\mathrm{a}$ & $\mathrm{b}$ & $\Delta \mathrm{E}$ \\
\hline \multicolumn{5}{c}{ Control } \\
\hline 0 & $93.22 \pm 0.50 \mathrm{ab}$ & $-2.50 \pm 0.09 \mathrm{a}$ & $13.55 \pm 0.14 \mathrm{~d}$ & $12.38 \pm 0.13 \mathrm{~d}$ \\
\hline \multicolumn{5}{c}{$\mathbf{8 0} \mathrm{C}$} \\
\hline 2 & $92.94 \pm 0.13 \mathrm{abc}$ & $-2.69 \pm 0.09 \mathrm{abc}$ & $14.89 \pm 0.95 \mathrm{~d}$ & $13.75 \pm 0.94 \mathrm{~d}$ \\
6 & $92.88 \pm 0.48 \mathrm{abc}$ & $-2.59 \pm 0.20 \mathrm{ab}$ & $15.43 \pm 0.69 \mathrm{~cd}$ & $14.26 \pm 0.77 \mathrm{~cd}$ \\
14 & $93.30 \pm 0.35 \mathrm{a}$ & $-2.46 \pm 0.10 \mathrm{a}$ & $15.08 \pm 0.25 \mathrm{~d}$ & $13.78 \pm 0.34 \mathrm{~d}$ \\
24 & $93.34 \pm 0.06 \mathrm{a}$ & $-2.44 \pm 0.05 \mathrm{a}$ & $15.41 \pm 0.66 \mathrm{~cd}$ & $14.09 \pm 0.66 \mathrm{~cd}$ \\
\hline \multicolumn{5}{c}{$95^{\circ} \mathrm{C}$} \\
\hline 2 & $92.41 \pm 0.12 \mathrm{bcd}$ & $-3.03 \pm 0.12 \mathrm{~d}$ & $17.78 \pm 0.48 \mathrm{bc}$ & $16.68 \pm 0.42 \mathrm{bc}$ \\
6 & $92.35 \pm 0.60 \mathrm{~cd}$ & $-2.97 \pm 0.09 \mathrm{~d}$ & $19.53 \pm 1.90 \mathrm{ab}$ & $18.36 \pm 1.96 \mathrm{ab}$ \\
14 & $92.77 \pm 0.08 \mathrm{abcd}$ & $-2.80 \pm 0.13 \mathrm{bcd}$ & $18.82 \pm 0.94 \mathrm{~b}$ & $17.55 \pm 0.90 \mathrm{~b}$ \\
24 & $92.03 \pm 0.70 \mathrm{~d}$ & $-2.92 \pm 0.23 \mathrm{~cd}$ & $21.67 \pm 2.91 \mathrm{a}$ & $20.47 \pm 2.99 \mathrm{a}$ \\
\hline
\end{tabular}

* Film color was measured after placing films on top of a standard white plate with Hunter color values of $\mathrm{L}=96.86, \mathrm{a}=-0.02$, and $\mathrm{b}=1.99$.

† Presented values are means of three replicates plus/minus a standard deviation. Any two means in the same column followed by the same small-case letter are not significantly different $(P>0.05)$ according to Duncan's multiple range test.

\section{CONCLUSIONS}

Properties of SPI films can be substantially modified by heat treatments, thus, helping tailor such films to specific packaging applications. Increased TS and reduced WS and WVP are all desirable heat-induced improvements of SPI film properties. However, the above property improvements come at the expense of decreases in film $\mathrm{E}$ (flexibility) and increased yellow color.

ACKNOWLEDGMENT. We acknowledge partial funding from the Nebraska Soybean Board.

\section{REFERENCES}

American Society for Testing and Materials. 1989. Annual Book of ASTM Standards. Philadelphia, Pa.: ASTM.

Brandenburg, A. H., C. L. Weller and R. F. Testin. 1993. Edible films and coatings from soy protein. J. Food Sci. 58(5):10861089.

Cheftel, J. C., J-L. Cuq and D. Lorient. 1985. Amino acids, peptides, and proteins. In Food Chemistry, 2nd Ed., ed. O.R. Fennema, 245-369. New York: Marcel Dekker, Inc.

Francis, F. J. and F. M. Clydesdale. 1975. Food Colorimetry: Theory and Applications. Westport, Conn.: The AVI Publishing Company, Inc.

Gennadios, A., A. H. Brandenburg, C. L. Weller and R. F. Testin. 1993a. Effect of $\mathrm{pH}$ on properties of wheat gluten and soy protein isolate films. J. Agric. Food Chem. 41(11):1835-1839.

Gennadios, A., H. J. Park and C. L. Weller. 1993b. Relative humidity and temperature effects on tensile strength of edible protein and cellulose ether films. Transactions of the ASAE 36(6): 1867-1872.
Gennadios, A., T. H. McHugh, C. L. Weller and J. M. Krochta. 1994a. Edible coatings and films based on proteins. In Edible Coatings and Films to Improve Food Quality, eds. J. M. Krochta, E. A. Baldwin and M. Nisperos-Carriedo, 201-277. Lancaster, Pa.: Technomic Publishing Company, Inc.

Gennadios, A., A. H. Brandenburg, J. W. Park, C. L. Weller and R. F. Testin. 1994b. Water vapor permeability of wheat gluten and soy protein isolate films. Industr. Crops Products 2(3):189-195.

Gennadios, A., C. L. Weller and C. H. Gooding. 1994c. Measurement errors in water vapor permeability of highly permeable, hydrophilic edible films. J. Food Eng. 21(4):395-409.

Ghorpade, V. M., H. Li, A. Gennadios and M. A. Hanna. 1995. Chemically modified soy protein films. Transactions of the ASAE 38(6): 1805-1808.

Gontard, N., S. Guilbert and J-L. Cuq. 1993. Water and glycerol as plasticizers affect mechanical and water vapor barrier properties of an edible wheat gluten film. J. Food Sci. 58(1):206-211.

Gregory, S. P. 1991. Physical properties of glycerine. In Glycerine: A Key Cosmetic Ingredient, eds. E. Jungermann and N. O. V. Sonntag, 113-156. New York: Marcel Dekker, Inc.

Howland, D. W. 1961. Curing prolamines. U.S. Patent 3,010,917.

Howland, D. W. and R. A. Reiners. 1962. Preparation and properties of epoxy-cured zein coatings. Paint and Varnish Production 52(2):31-34, 78.

Julius, A. 1967. Food wrapping membrane. U.S. Patent 3,329,509.

Kolster, P., H. J. Kuiper and J. M. Vereijken. 1992. Non-food applications of wheat gluten. AACC Paper No. 68.172. Annual Meeting of the Am. Assoc. of Cereal Chemists. Minneapolis, Minn., 20-23 September.

McHugh, T. H., R. Avena-Bustillos and J. M. Krochta. 1993. Hydrophilic edible films: Modified procedure for water vapor permeability and explanation of thickness effects. J. Food Sci. 58(4):899-903.

Roy, S., C. L. Weller, M. G. Zeece and R. F. Testin. 1995. Effect of heat on the physical and molecular properties of wheat gluten films. Paper No. 12E-14. Annual Meeting of the Institute of Food Technologists. Anaheim, Calif., 3-7 June.

SAS Institute. 1988. SAS/STAT User's Guide. Release 6.03. Gary, N.C.

Shih, F. F. 1994. Interaction of soy isolate with polysaccharide and its effect on film properties. J. Agric. Food Chem. 71(11):12811285.

Smith, P. K., R. I. Krohn, G. T. Hermanson, A. K. Mallia, F. H. Gartner, M. D. Provenzano, E. K. Fujimoto, N. M. Goeke, B. J. Olson and D. C. Klenk. 1985. Measurement of protein using bicinchoninic acid. Anal. Biochem. 150(1):76-85.

Stuchell, Y. M. and J. M. Krochta. 1994. Enzymatic treatments and thermal effects on edible soy protein films. J. Food Sci. 59(6):1332-1337. 